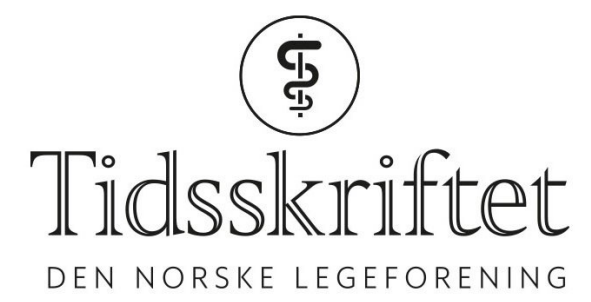

\title{
Ambulansetjenesten i Nord-Norge
}

LEDER

\section{TORBEN WISBORG}

E-post: torben@wisborg.net

Torben Wisborg (f. 1956) er anestesiolog, forskningsleder i Nasjonal kompetansetjeneste for traumatologi, professor ved Universitetet i Troms $\varnothing$ - Norges arktiske universitet og overlege ved Akuttavdelingen, Hammerfest sykehus. Han er medlem av redaksjonskomiteen i Tidsskriftet. Forfatter har fylt ut ICMJE-skjemaet og oppgir ingen interessekonflikter.

Ambulansetjenesten er en del av spesialisthelsetjenesten, men også et uunnværlig ledd $\mathrm{i}$ behandlingskjeden for pasienter, primærhelsetjeneste og spesialisthelsetjeneste. Når et ledd svikter, brytes kjeden.

Helseforetakene og de regionale helseforetakene har ansvar for ambulansetjenesten. Nordland, Troms og Finnmark fylker utgjør $35 \%$ av Norges areal, og $10 \%$ av den norske befolkningen bor i Nord-Norge. Helseforetakene benytter ambulansebiler, ambulansebåter og ambulansefly for å sikre befolkningen en forsvarlig ambulansetjeneste. Av geografiske og klimatiske grunner er denne kombinasjon nødvendig for å oppfylle regjeringens og Stortingets mål, som årlig bekreftes i nasjonalbudsjettet: «Alle skal ha tilgang til likeverdige helsetjenester av god kvalitet» (1).

Luftambulansetjenesten er organisert på et nasjonalt nivå av de fire regionale helseforetakene og drives av Luftambulansetjenesten HF, som eies av de regionale helseforetakene. Luftambulansetjenesten HF har ansvar for den flyoperative delen av ambulansetjenesten i Norge og kjøper tjenestene fra kommersielle aktører og Justis- og beredskapsdepartementet (redningshelikoptertjenesten). Helseforetakene har ansvaret for helsepersonellbemanningen. Tjenesten har ni ambulansefly plassert på syv baser: Gardermoen (to fly), Ålesund, Brønnøysund, Bodø, Tromsø, Alta (to fly) og Kirkenes.

Kjøp av flytjenester gjøres som anbudsprosesser. Det er Luftambulansetjenesten HF som anskaffer ambulansefly- og ambulansehelikoptertjenester og inngår kontrakt med flyselskapene (2). Etter opprettelsen av helseforetakene i 2002 er de fleste bilambulansetjenestene blitt en del av helseforetakene, der ansatte og utstyr er organisert direkte i helseforetakene uten bruk av private leverandører, «insourcing». Dette har gitt tjenestene et stort faglig løft og personellet bedre arbeidsvilkår, noe som både fører til stabilitet og bedre pasientbehandling.

Da Luftambulansetjenesten HF tildelte kontrakt for levering av flytjenester fra 1.7.2019 til en ny operatør, krevde de ikke at personell fra den gamle operatøren skulle følge med til den nye operatøren. Den nye operatøren skal derfor ansette nytt personell, og den gamle operatørens personell mister sin nåværende jobb når kontrakten utløper sommeren 2019. Resultatene er kjent fra mediene og har ført til en krise i ambulanseflytjenesten, som går ut over helsetilbudet til befolkningen i hele Nord-Norge. 
Er ambulansetjenesten relevant for Tidsskriftets lesere? Ja. Hver dag bruker leger i kommunal legevakt ambulanser, det være seg bil, båt eller fly/helikopter, for å få transportert og behandlet sine pasienter underveis til høyere behandlingsnivå. På samme måte er leger i sykehus avhengig av tjenesten for å flytte pasienter til spesialisert behandling og tilbake til sine hjemsteder. Spesielt i Nord-Norge er ambulansefly en naturlig ressurs for transport der man andre steder i landet bruker ambulansebil. Som eksempel er avstanden på vei fra Gamvik til Hammerfest 386 km eller 5 timer og 46 minutter, og tilsvarende Berlevåg til Kirkenes 277 km eller 3 timer og 53 minutter (3). Til sammenligning er avstanden fra Oslo til Trondheim 494 km eller 6 timer og 42 minutter.

Et sviktende ledd i den akuttmedisinske transport- og behandlingskjeden er altså et medisinsk problem som rammer pasienter og helsepersonell, og forhindrer målet om å tilby likeverdige tjenester av god kvalitet.

Nå brukes det store beløp av fellesskapets penger til å opprettholde beredskapen. Helse Nord anslår at det brukes minimum 1,6 millioner kr per uke på innleie av fly, helikopter og ekstra beredskap av helsepersonell (4). Dette er et problem for et helsevesen som allerede har økonomiske begrensninger, og vil selvsagt ramme pasientene før eller senere.

På samme måte som legevaktsentraler og sykehus trenger konstant forsyning av vann og strøm, er det behov for en forutsigbar ambulansetjeneste. Ambulansetjenesten er nøkternt dimensjonert, og når tjenesten fungerer, dekker både ambulansebiler, -båter og -fly stort sett behovene. Det er ikke behov for nye ambulansehelikopterbaser eller andre tiltak som kommersielle aktører ganske sikkert vil foreslå i kjølvannet av denne uholdbare, men varslede situasjon. Det er behov for fortsatt forutsigbar tilgang på alle eksisterende deler av ambulansetjenesten.

En samfunnsmessig krise har oppstått som følge av det som fremstår som bevisste valg i en kommersiell prosess, der forvalterne av fellesskapets penger ikke har maktet eller villet forutse konsekvensene av å drive helsetjenester etter anbudsordning. Befolkningen fortjener - og helsepersonell forventer - at en uunnværlig infrastruktur i helsevesenet forvaltes med forståelse for at en kjede ikke er sterkere enn det svakeste leddet.

Bilambulansetjenesten er stort sett overtatt av helseforetakene selv med godt resultat. Ambulanseflytjenesten må også sikres, og anbudsordningen uten overføring av personell har vist seg ute av stand til å opprettholde denne samfunnskritiske funksjonen.

LITTERATUR:

1. Regjeringen. Prop. 1 S (2017-2018) for budsjettåret 2018.

https://www.regjeringen.no/no/dokumenter/prop.-1-s-ud-20172018/id2574542/(6.6.2018).

2. Luftambulansetjenesten HF.

http://www.luftambulanse.no/forankring-og-fullmakt-til-\%(3\% 35 -anskaffe-ambulanseflytjenester-i-rhfene (6.6.2018).

3. Google Maps.

https://www.google.no/maps/dir/Hammerfest+sykehus,+Sykehusveien,+Hammerfest/9775+Gamvik/@ 70.5536221,24.8249812,8z/data=!3m1!4b1!4m14!4m13!1m5!1m1!1sox45c8bbb26775ffc5:0x7743237cbb13561 1 !2m2!1d23.6723724!2d70.6727035!1m5!1m1!1sox45ca1e75bb519521:0xa7f3daa25a2co8b2 !2m2 !1d28.24406 68 !2d71.0618o8!3eo (6.6.2018).

4. Helse Nord.

https://helse-nord.no/nyheter/kostnader-for-a-opprettholde-beredskap-pa-ambulansefly (6.6.2018).

Publisert: 26. juni 2018. Tidsskr Nor Legeforen. DOI: 10.4045/tidsskr.18.0501

(C) Tidsskrift for Den norske legeforening 2020. Lastet ned fra tidsskriftet.no 